
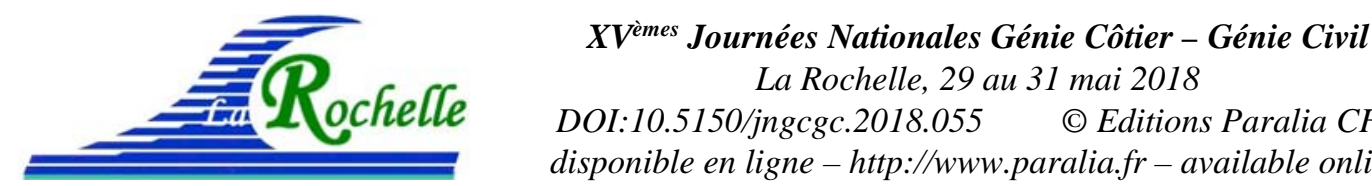

DOI:10.5150/jngcgc.2018.055 ～(C) Editions Paralia CFL

disponible en ligne - http://www.paralia.fr - available online

\title{
Coastal protection jetty with geotextile tubes core and artificial beach creation in Tocopilla, Chile
}

\author{
Matheus MÜLLER ${ }^{1}$, Eduardo GUANAES ${ }^{2}$, Delma VIDAL ${ }^{3}$
}

1. ITA, Instituto Tecnológico de Aeronáutica, Praça Marechal Eduardo Gomes, 50, Vila das Acácias, 12228-900 São José dos Campos/SP - Brasil.

mrlmuller@gmail.com

2. HUESKER, Av. Dr. Sebastião Henrique da Cunha Ponte, 8.000, Galpão E, Chácaras Reunidas, 12238-365 São José dos Campos/SP - Brasil.

eduardo@huesker.com.br

3. ITA, Instituto Tecnológico de Aeronáutica, Praça Marechal Eduardo Gomes, 50, Vila das Acácias, 12228-900 São José dos Campos/SP - Brasil.

delma@ita.br

\begin{abstract}
:
The present article describes the design, field tests and execution of jetties for coastal protection in the creation of the first artificial beach protected with geotextile tubes in Chile, El Salitre, in the city of Tocopilla. The construction process consider geotextile tubes filled with local sand, functioning as the core of the jetties, arranged in up to three levels, installed in adverse conditions and at great depths $(\sim 10 \mathrm{~m})$. The tubes are made with polypropylene woven geotextiles, having nominal tensile strength of $200 \mathrm{kN} / \mathrm{m}$ in both directions. The design included not only the economy of rocks, due to the lack of this resource in the surroundings, but also the encapsulation of a large part of the sand contaminated by coal and some heavy metals $\left(9.110 \mathrm{~m}^{3}\right)$ due to inadequate disposal at a nearby power station. Also, a large amount of contaminated sand was used to level the beach bed, after that receiving geotextile protection and a new layer of white sand. The objective of the work was to improve the quality of life of the local population, through the creation of a beach area suitable for human use, with the placement of a volume of approximately $28.400 \mathrm{~m}^{3}$ of white sand, protected by the artificial jetty, having total length of $550 \mathrm{~m}$. Finally, this project benefited more than 27 thousand people, contributing to the improvement of the quality of life and providing development to the region.
\end{abstract}

Keywords:

Jetty, Costal protection, Artificial beach, Geotextile tubes, Contaminated sand.

\section{Introduction}

Geotextiles have been increasingly used in engineering works since the beginning of their use in the mid-1950s (KOERNER, 2005). The use of geotextiles sewn in the form 


\section{Thème 4 - Ouvrages portuaires, offshore et de plaisance}

of a tube, hydraulically filled with sand or similar, was started in coastal protection works in the 1980s and, due to its success, remains until today (PILARCZYK, 2000).

A geotextile tube corresponds to a receptacle made up of a suitable geotextile, assuming a linear tubular shape through its filling, being able to be made in a variety of perimeters, lengths and consequently volumes.

These systems can be filled with a wide variety of materials such as sand, mining waste, sludge, thus being applicable for various purposes such as coastal protection and effluent dewatering (KOERNER, 2005; PILARCZYK, 2000). The success of this technology was provided by the ability of the geotextile to retain inside the tube the solid particulate of the dredged material, while allowing the liquid part to exit through its pores, then having a good filtering function, applicable for various purposes (MOOYOUNG et al., 2002).

Geometric study and tensions acting on the geotextile must be performed to size the system and verify its operation and integrity. There are several calculation methods for these factors (LESHCHINSKY \& LESHCHINSKY, 1996; LIU, 1981; KAZIMIEROWICZ, 1994; CARROLL, 1994), there is also the possibility of using softwares, such as GeoCoPS, to study the shape and stresses in a geotextile tube (LESHCHINSKY \& LESHCHINSKY, 1996). The design must consider the geotextile behavior under mechanical, hydraulic and environmental requirements throughout the service life of the work. Geotextile tubes are widely used in dredging of contaminated fluvial and maritime sludge, in construction of containment dams filled with fluvial, maritime and industrial sludge, among others (KOERNER, 2005; PILARCZYK, 2000). Figure 1 shows an example of application of geotextile tubes in coastal protection.

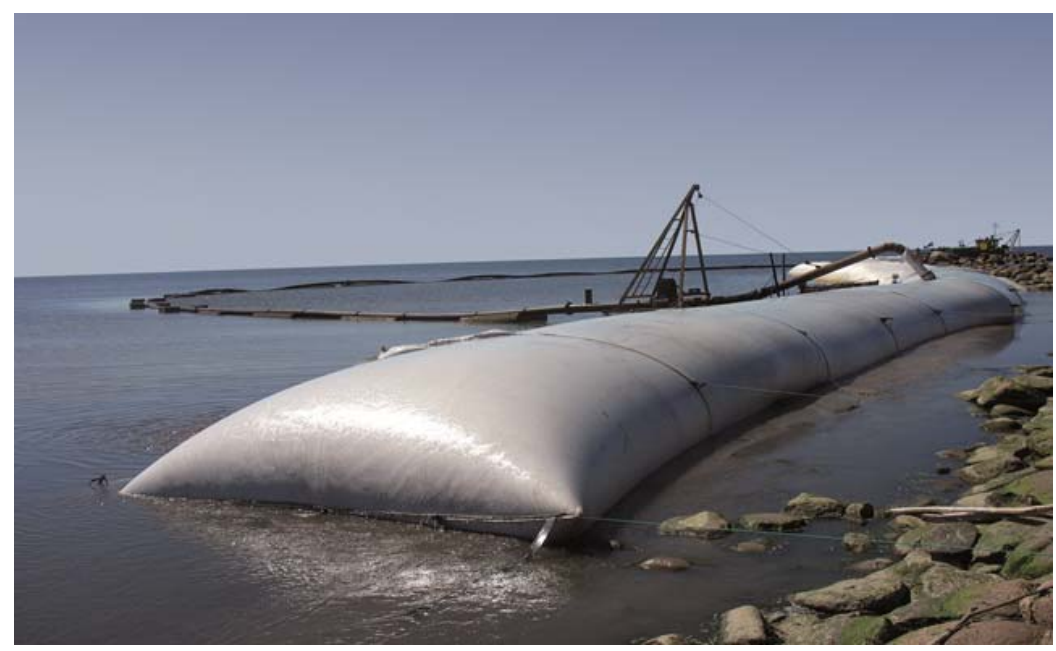

Figure 1. Geotextile tube used for coastal protection. 


\section{XVèmes Journées Nationales Génie Côtier - Génie Civil \\ La Rochelle, 29 au 31 mai 2018}

\section{Case study}

The case covered includes the construction of the first artificial beach of Chile protected with geotextile tubes, located in Tocopilla, $1.532 \mathrm{~km}$ from Santiago (capital of Chile) in the north of the country. El Salitre beach is close to a port region that serves a local thermoelectric plant, as can be seen in figure 2. Due to the incorrect provision of mineral coal, the beach sand was contaminated with this material and unfit for use by the local population.

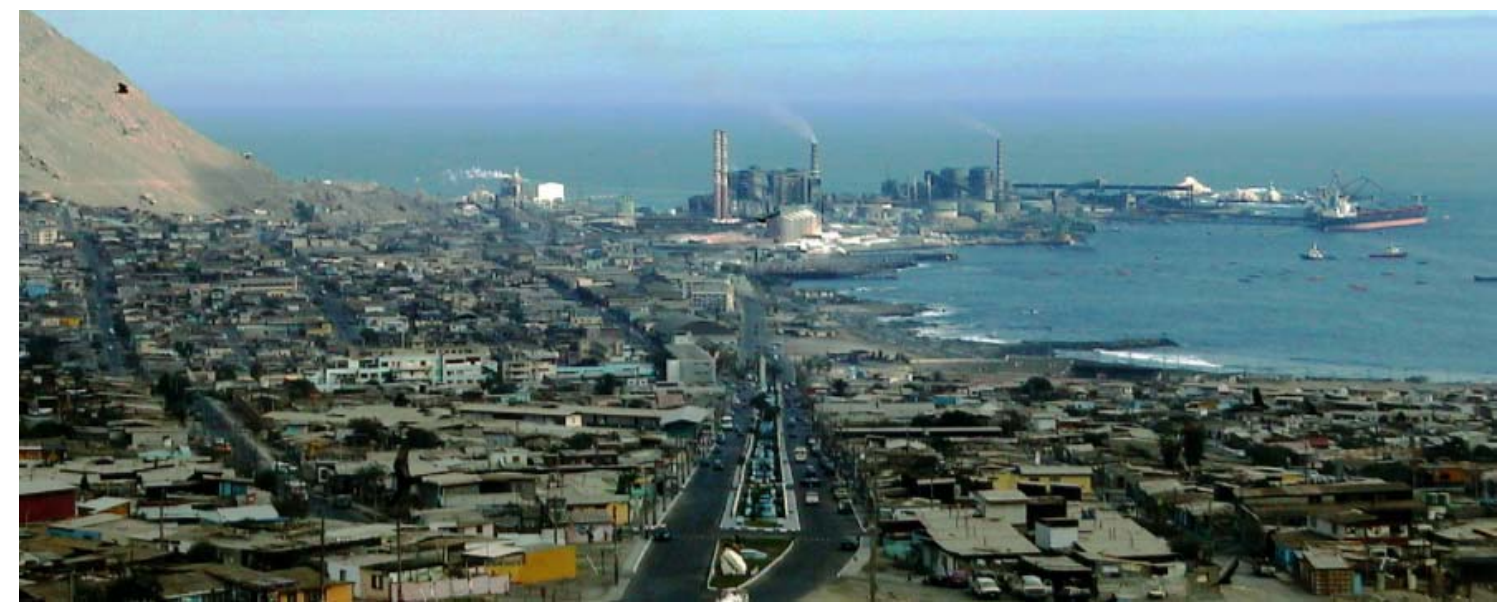

Figure 2. El Salitre beach and port region before the construction work.

The initiative to revitalize the beach El Salitre aimed to improve the quality of life of the local population, 27.000 inhabitants, by investing US\$ 7,5 million to regularize port activities and build the artificial beach.

The construction of two jetties and a submerged dam was evaluated as the best solution for El Salitre, providing $250 \mathrm{~m}$ of beach by dredging and encapsulating $9.110 \mathrm{~m}^{3}$ of contaminated sand in the core of the jetties for coastal protection, followed by the replacement of $28.400 \mathrm{~m}^{3}$ of clean white sand to the beach area. Figure 3 shows a schematic of the solution found.

The solution was then defined in the construction of two main jetties, north jetty with $120 \mathrm{~m}$ and south jetty with $199 \mathrm{~m}$, these made with cores in geotextile tubes, with encapsulated contaminated sand, and cover in rocks. In addition to the submerged central dike with $50 \mathrm{~m}$ long, made with rocks.

The studies for the work began in December 2015, with a forecast for the completion of the project until December 2017 and the inauguration of the El Salitre artificial beach in February 2018. The piers were completed in November, within the established schedule. 


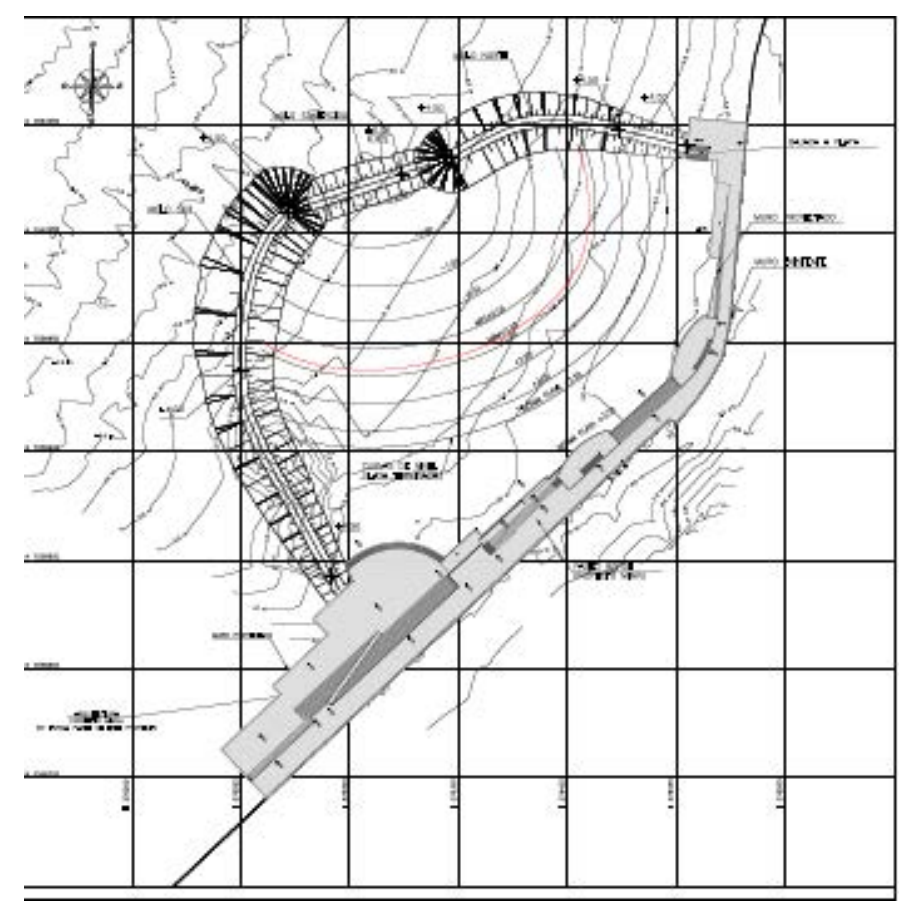

Figure 3. Supported solution for El Salitre beach.

\section{Project steps}

\subsection{Design of jetties}

Figure 4 shows the general configuration chosen for the jetties, which are composed of a core of geotextile tubes, covered by layers of rock that should function as a hydraulic sink. In order to avoid erosive processes in the foundation, the region of the base, considered most exposed, is protected by a special layer known as the scour apron with mantle, having $6,0 \mathrm{~m}$ wide and maintaining at least $2,5 \mathrm{~m}$ of mantle outside the core structure of geotextile tubes.

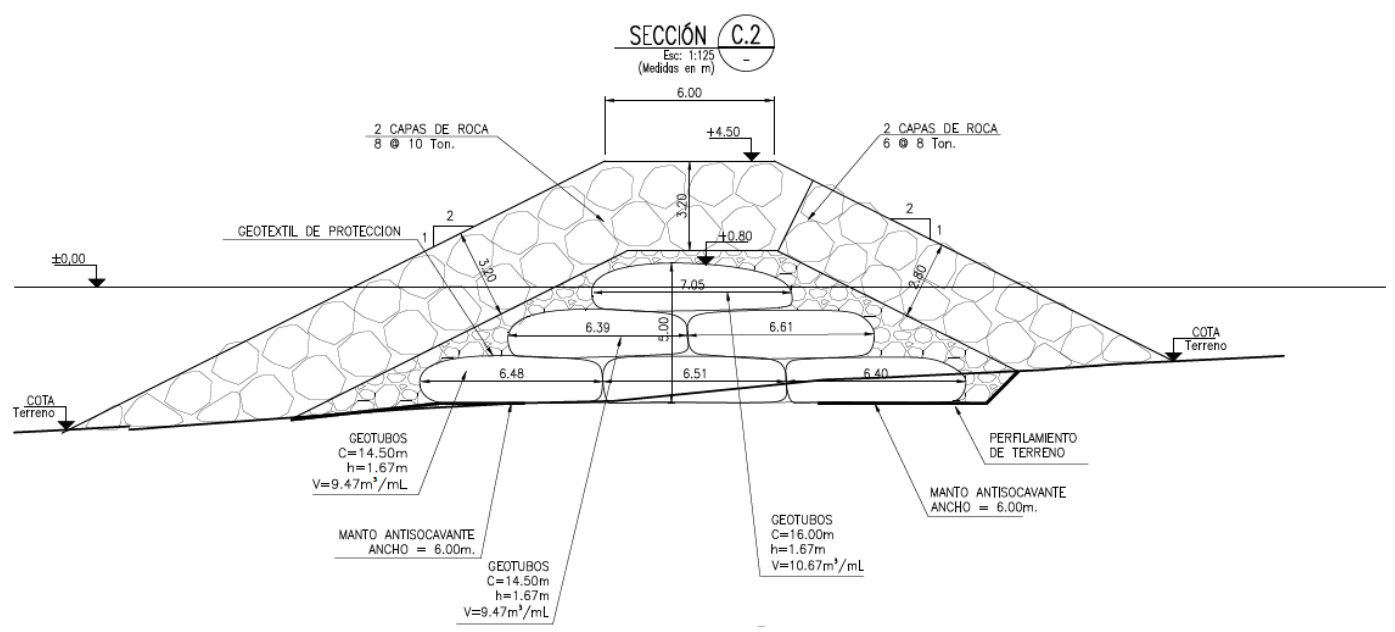

Figure 4. Cross section of the jetty with three layers of overlapping geotextiles. 


\section{XVèmes Journées Nationales Génie Côtier - Génie Civil \\ La Rochelle, 29 au 31 mai 2018}

Both jetties have one to three levels of overlap of geotextiles tubes to ensure the required height of the piers as the depth of the structure progresses. These tubes are mechanically stabilized after filling and protected from possible damage during the laying of the covering stones by a non-woven geotextile (Bidim OP 50) with $500 \mathrm{~g} / \mathrm{m}^{2}$ mass per unit area. It is also important to emphasize that the nonwoven geotextile layer contributes not only to mechanical protection but also as a filtering layer.

The jetties advance until a depth of approximately 4,5 $\mathrm{m}$ in the Pacific Ocean, the local oceanic currents are parallel to the cost, having its flow from the port to the artificial beach and, being so, protected by the jetties. Also, having wave heights varying from a minimum of $0,23 \mathrm{~m}$ to $1,13 \mathrm{~m}$.

The south jetty has its core consisting of 40 geotextile tubes on scour aprons with mantles and the north jetty by 12 geotextiles on scour aprons with mantles, as shown in figure 5 .

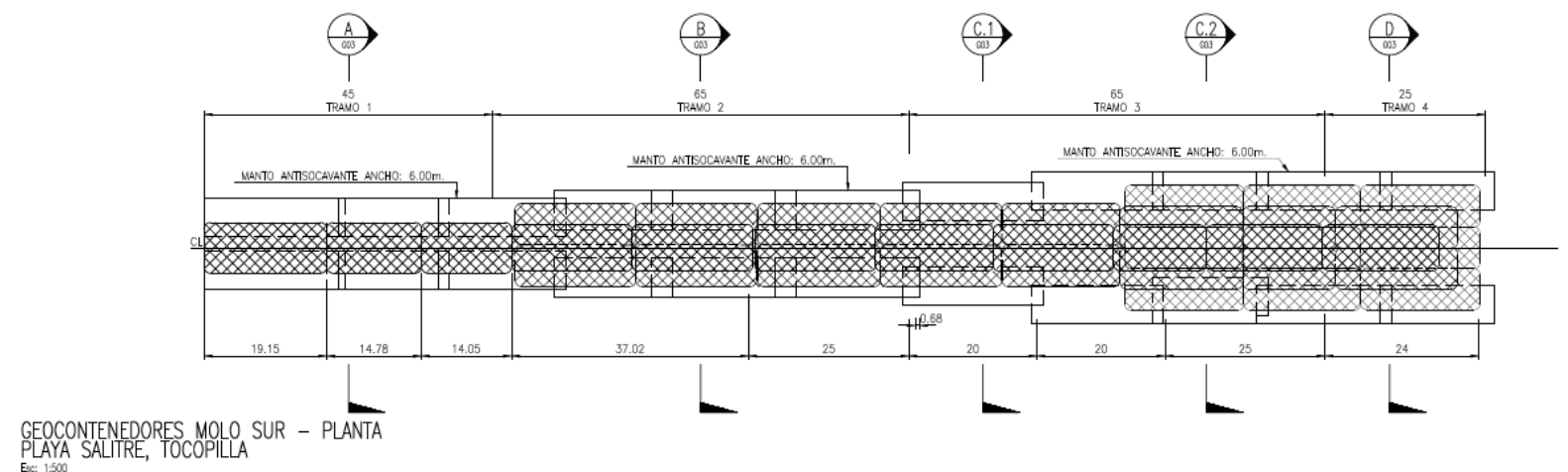

(a) South jetty.

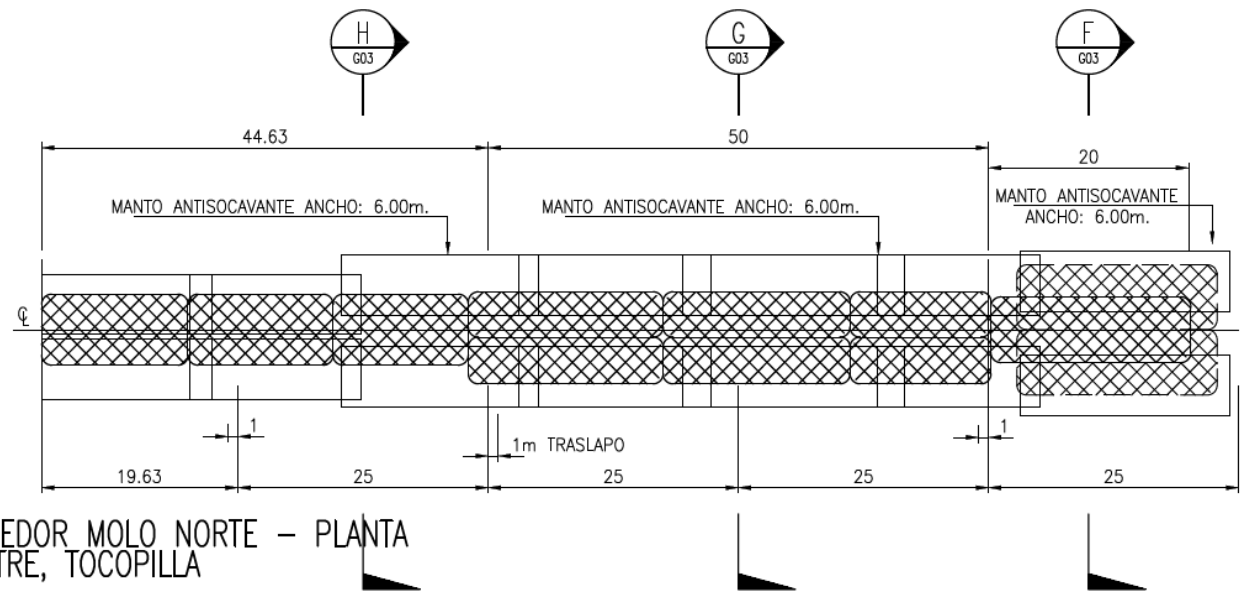

(b) North jetty.

Figure 5. Cores in geotextile tubes of the south and north jetties. 


\section{Thème 4 - Ouvrages portuaires, offshore et de plaisance}

The cover of the geotextile tube core was made with protective rocks with rocks from 0,3 to 0,5 ton as filter layer, 2,0 to 8,0 ton as internal shell and 6,0 to 10,0 ton as outer shell.

\subsection{Design and selection of geotextiles for the manufacture of tubes}

For the analysis of the geometry and the operating stresses, the methodology of LESHCHINSKY \& LESHCHINSKY (1996) was used through the software GeoCoPS 3.0. The geometric results for the worst case scenario are represented in figure 6 , with a shape factor of 0,323 . (height divided by the width of a tube).

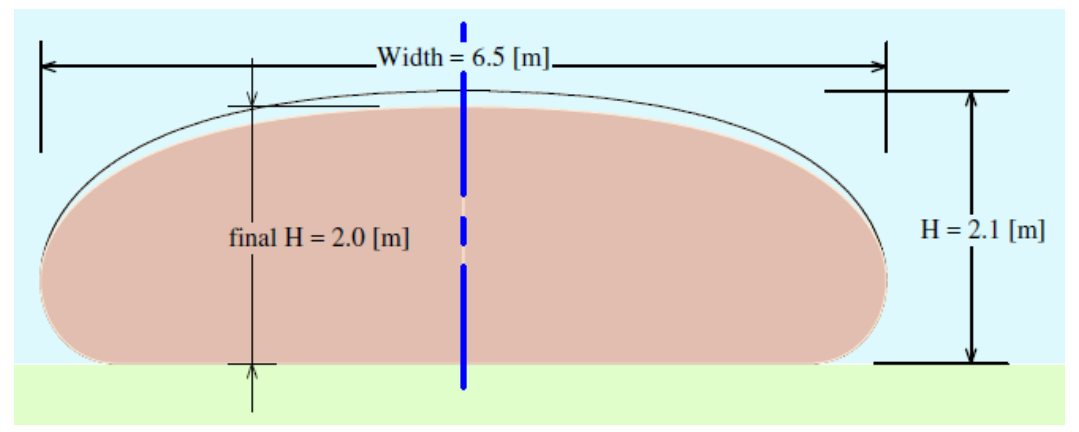

Figure 6. GeoCoPS 3.0 geometric results.

After tensile stress analysis during filling and during the service life of the geotextile in each situation, the project opted for a tensile strength of the geotextile at rupture of $200 \mathrm{kN} / \mathrm{m}$ in both directions (minimum value guaranteed by the manufacturer). Product that considers the various reduction factors that could occur in the field (splicing, installation damage, creep, environment and weathering) and still presents satisfactory tensile strength available, satisfying the calculated demands.

The geotextile chosen was the SoilTain PP 200/200 CP, having the necessary characteristics for the project, also having characteristic filtration opening (NBR ISO 12956) of $0,30 \mathrm{~mm}$. Being so, before the contaminated sand granulometry of more than $0,32 \mathrm{~mm}$ and through field tests in real scale and calculation methodology for retention of particles (BEZUIJEN \& VASTENBURG, 2013), the geotextile was approved for confection of the tubes.

Due to the existing efforts, especially in filling of the tubes, the seams were designed to be predominantly in transverse directions, connecting one strip of geotextile to the other, having only one longitudinal seam at its base, which has direct contact with the ground, as recommended PILARCZYK (2000). It is also emphasized the need for wellmade and localized seams, since seams are the points of least resistance in the physical system of a geotextile tube.

Thus, for the determination of the reduction factor by splicing, the project considered for the manufacture of geotextile tubes, "overlapping" type seams, with 6 lines of 


\section{$X V^{\text {èmes }}$ Journées Nationales Génie Côtier - Génie Civil \\ La Rochelle, 29 au 31 mai 2018}

polyester of high tenacity on its circumference, and type "J", with two lines of high tenacity polyester in their longitude. Which represent for the selected product reduction factors (ratio of the tensile strength of the seamless product and the tensile strength of the product after sewing) of 1.1 and 1.4 respectively.

Since the filled geotextile tubes could be subjected to solar radiation for a few days, one of the requirements for the selection of the geotextile was its additivation to the UV rays, that is, that the product presented resistance to traction retained after accelerated tests of weathering satisfying the requirements of ISO TS 13434. The manufacturer recommends the selected geotextile for periods of exposure to weathering of up to $4300 \mathrm{~h}$, for application under long-term traction requests, based on test results considering exposure to UV radiation of $50 \mathrm{MJ} / \mathrm{m}^{2}$.month carried out according to DIN EN 12224 (2000). This energy represents the expected UV radiation for a summer month in southern Europe. However, northern Chile is subjected to much higher levels of UV radiation (ESCOBAR et al., 2014, for example), which requires specific care with the time and period of exposure. Considering that the exposure period would be less than 30 days and that the work would take place during the winter months, special reduction factors for exposure to weathering were not necessary.

\section{Execution and constructive care}

Considering that the stability of the geotextiles during filling would occur under severe conditions, the project predicted a real-scale test in a critical situation of surfacing to evaluate the difficulties in the installation/positioning in terms of stability to wave attack and stability to currents (BEZUIJEN \& VASTENBURG, 2013).

The test carried out led to the development of an equipment for the installation of the scour apron systems and the geotextile tubes that would guarantee its stability before filling, avoiding the movement of the empty components.

These tests also indicated the interest of beginning the construction of the piers by placing the cladding rocks around the installation area of the scour apron systems and the geotextile tubes by sections, functioning as hydraulic sinks already during the installation and filling phase of the tubes. To better guarantee the stability and positioning of the empty elements, a crane with 13 tons metallic structure for allocation was developed. The metal structure collaborating with the maintenance of the positioning of the elements until they gained sufficient weight and stability to guarantee their positions.

For the dredging of local contaminated sand and filling of the geotextile tubes, a pump with suction working capacity of up to $65 \%$ solids and up to $220 \mathrm{~m}^{3} / \mathrm{h}$ was used.

Once the tubes were filled, the mechanical protection element (non-woven geotextile of $500 \mathrm{~g} / \mathrm{m}^{2}$ ) was fixed on the cores of the jetties, so that the rock cover for filtration (300 to $500 \mathrm{~kg}$ ) and then rock cover for dispersion (2 to 4 ton) were allocated. 


\section{Thème 4 - Ouvrages portuaires, offshore et de plaisance}

\section{Conclusions}

Above all, it can be seen that the work may bring more quality of life to the local population, valuing the region and providing local economic growth. Illustrative image of the completed work can be seen in figure 7 .

The work faced challenges for the allocation of scour apron systems and geotextile tubes, since these empty elements were easily carried by waves and tides. Thus, metal structure with sufficient weight to keep the elements in place until their satisfactory filling was developed and used. Still, corroborating with this filling process, the very rocks that would serve as cover were located around the area of installation of the elements, dissipating waves and facilitating the work.

Due to the high pumping capacity of the pump used, there was a case of rupture of a tube, which was repaired. This occurrence was quickly evaluated and from there all filling nozzles of the geotextiles were kept open until the filling was complete.

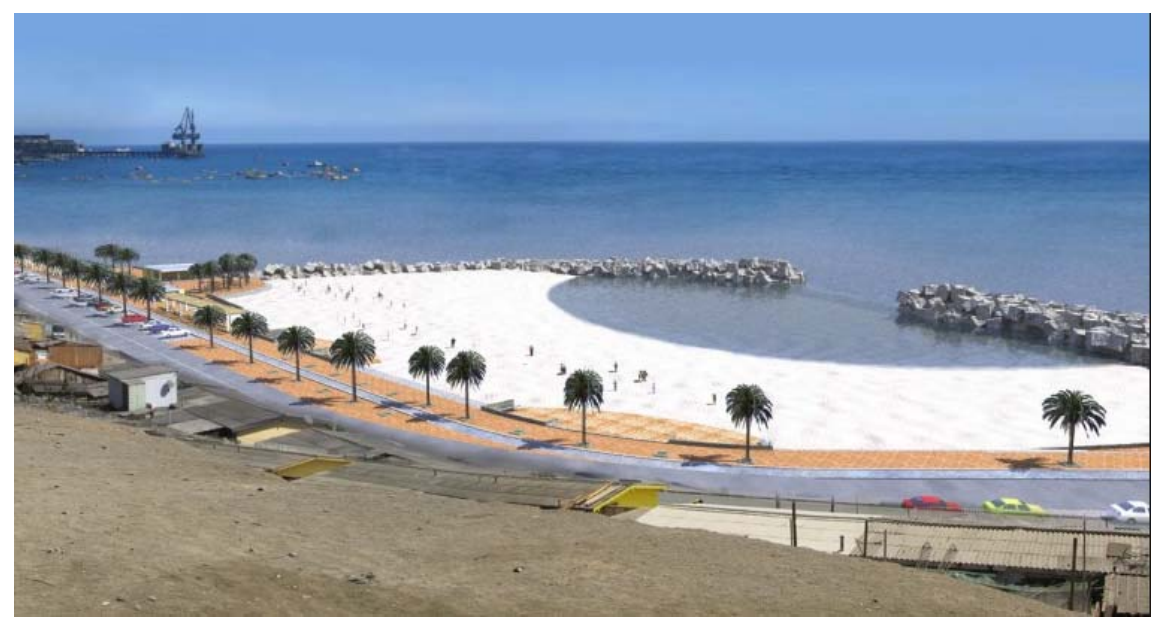

Figure 7. El Salitre beach completed (Geosistemas).

\section{References}

ABNT. Associação brasileira de normas técnicas. NBR ISO 12.956 (2013) Geotêxteis e produtos correlatos - Determinação da abertura de filtração característica.

BEZUIJEN A., VASTENBURG E.W. (2013). Geosystems: Design rules and applications. CRC Press, 1. Ed., Chennai, India.

CARROLL R.P. (1994). Submerged geotextile flexible forms using noncircular cylindrical shapes. Geotechnical Fabrics Report, IFAI. 12(8). pp. 4-15.

DIN EN 12224. (2000). Geotextiles and geotextile-related products - Determination of the resistance to weathering. German version EN 12224:2000.

ESCOBAR R.A., CORTÉS C., PINO A., PEREIRA E.B., MARTINS F.R. CARDEMIL J.M. (2014). Solar energy resource assessment in Chile: satellite estimation and ground station measurements. Renewable energy, Vol. 71, pp 324-332. https://doi.org/10.1016/j.renene.2014.05.013 


\section{XVèmes Journées Nationales Génie Côtier - Génie Civil \\ La Rochelle, 29 au 31 mai 2018}

ISO-TS 13434 Geosynthetics. Guidelines for assessment of durability.

KAZIMIEROWICZ K. (1994). Simple analysis of deformation of sand-sausages. Proceedings of the 5th International Conference on Geotextile, Geomembranes and Related Products, Singapore, pp.775-778.

KOERNER R.M. (2005). Designing with Geosynthetics. Pearson, 5. Ed. Upper Saddle River, N.J.

LESHCHINSKY D. LESHCHINSKY O. (1996). GeoCoPs 2.0 Supplemental Notes. ADAMA Engineering, USA, $24 \mathrm{p}$.

LIU G.S. (1981). Design criteria of sand sausages for beach defences. The 19th Congress of the International Association for Hydraulic Research, New Delhi, India. Subject B(b), Paper No. 6. pp 123-131.

MOO-YOUNG H.K., GAFFNEY D.A., MO X. (2002). Testing procedures to assess the viability of dewatering with geotextile tubes. Geotextiles and Geomembranes, Vol. 20, pp 289-303. https://doi.org/10.1016/S0266-1144(02)00028-6

PILARCZYK K.W. (2000). Geosynthetics and geosystems in hydraulic and costal engineering. A.A.Balkema, 1. Ed., Netherlands. 
Thème 4 - Ouvrages portuaires, offshore et de plaisance 